\title{
The significant role of religious group's response to natural disaster in Indonesia: the case of Santri Tanggap Bencana (Santana) ${ }^{1}$
}

\author{
Mohammad Rokib
}

Research Fellow in the Southeast Asia Regional Exchange Program (SEASREP) Foundation; Lecturer at the Muhammadiyah University of Surabaya

E-mail:emrokib_84@yahoo.com

\begin{abstract}
Natural disasters, which occur regularly in Indonesia, have inspired many volunteer groups to emerge from different groups of society, including religious group. This paper focuses on the experiences of the religious volunteer group called Santana (I slamic student's response to disaster) in East J ava region. The group is part of I slamic education institution (pesantren) that emphasizes religious aspects and attempts to realize religious values in everyday life. The group gives religious meaning to the experience of disaster and the efforts to help disaster
\end{abstract}

\footnotetext{
${ }^{1}$ This article was based on "Religion and Natural Disaster" project funded by Center for Religious and Cross Culture Studies (CRCS), Gadjah Mada University under Heddy Shri AhimsaPutra supervision. Besides, this was presented in the $6^{\text {th }}$ Asian Graduate Forum on Southeast Asian Studies, Singapore, 11-15 J uly 2011. The author would like to thank participants for their earlier version of this paper. R. Michael Feener, Patrick Daly, and Levi McLaughlin provided some useful criticism and suggestions. Special thank to Kay Mohlman for her academic English support relate to this article.
} 
victims. The aim of this study is to describe Santana's response to natural disaster as not only a natural but also a cultural phenomenon. This study reveals a large number of religious symbols referring to disaster as natural and theological phenomena. Referring to the religious text, disaster victims are categorized by Santana as weak people (mustad'afin). It has inspired this group to engage in their social activism. Their commitment to the religious tenets involves not only giving material aid but also promoting spiritual empowerment. This gives insight into the dynamic of how religious groups manifest their religious values by providing both material and spiritual aid.

Bencana alam yang terjadi hampir setiap tahun di I ndonesia telah mendorong kemunculan kelompok relawan dari berbagai elemen masyarakat, termasuk kelompok agama. Artikel ini terfokus pada pengalaman relawan dari kelompok agama bernama Santana (santri tanggap bencana) di J awa Timur. Kelompok relawan ini merupakan bagian dari lembaga pesantren yang menekankan aspek keagamaan serta berusaha merealisasikan nilai-nilai keagamaan dalam kehidupan sehari-hari. Kelompok ini memberikan pemaknaan keagamaan pada kejadian bencana alam sekaligus berusaha menolong korban bencana. Tujuan studi ini adalah mendeskripsikan tanggapan kelompok Santana atas bencana alam yang tidak hanya sebagai kejadian alam melainkan juga fenomena (perubahan) kebudayaan. Artikel ini menyatakan bahwa terdapat sebuah gundukan simbol keagamaan yang menempatkan bencana sebagai peristiwa alam dan fenomena teologis. Dengan merujuk pada teks keagamaan, korban bencana dikategorikan oleh Santana sebagai orang lemah (Mustad'afin). Konsep ini mendorong mereka melakukan aktivisme sosial. Komitmen mereka atas ajaran agama tidak hanya telah memunculkan pertolongan material tetapi juga penguatan spiritual para korban bencana.

Keywords: Religious group; Santana; Religious meaning; Natural disaster

\section{Introduction}

Indigenous people in Indonesia assume natural disaster events as not only natural but also social phenomena. They believe it as agent of 
material destruction in the context of natural occurrence, while in the social phenomenon as agent of social change. In the process of natural events, disaster usually "produces condition of environmental vulnerability". ${ }^{2}$ The condition of vulnerability has raised the threat of health, hunger, homeless, and jobless. Because of creating human suffering, natural disaster events arouse the social responses either from the government or non-government organizations including religious groups.

In 2009 to 2012, because various natural disaster such as flood, earthquake, and mountain eruption caused billions of people injured, refugee, and killed, there was religious volunteer group that provided material and immaterial aid. This group used white headband which is inscribed with "Santana" word. It word is an acronym of santri tanggap bencana (I slamic student's response to disaster). This group provided both material supports such as general medical checkup, evacuation, rice, instant noodles and spiritual support such as massive praying in the refugees place. Indeed, based on my observation, the victims not only need material supports but also spiritual support to awake from despondent and traumatic experience. The group's method goes to deal with victim's resurrection.

The wolunteers of Santana group emphasized religious and/or spiritual assistant to the victims as well as material aids. They asked victims to pray together in order to gain the spiritual enlightens and avoid the traumatic imaginations. According to this group, this way is important aid beside the other physical aids, particularly in the religious society such as in Lamongan, East Java, Indonesia. This assistanship is not only appropriate for religious people but for all human beings also.

\footnotetext{
${ }^{2}$ Anthony Oliver-Smith, "Anthropological Research on Hazards and Disasters", Annual Review of Anthropology, 25 (1996), 305.
} 
In the Katharina hurricane, for example, Francis Gunn provided ten reasons about the importance of religious assistantship or religious group role in helping the victims. ${ }^{3}$ Religious leaders have potential roles to awaken the victims through spiritual advises, prayer or salat, ${ }^{4}$ solaces, and disseminated information ${ }^{5}$. Because religion is an integral part for Indonesian society, ${ }^{6}$ religious practices become spiritual aid for strengthening disaster victims.

Here, I consider natural disaster as a socio-cultural phenomenon because it involves human responses and interpretations, particularly for Santana volunteerism activity who lived in the boarding school (pesantren) near flood disaster area. As socio-cultural phenomena, natural disasters can be positioned as a text which makes it possible to be interpreted and understood. ${ }^{7}$ In this sense, text in the form of socio-cultural phenomenon will be understood and interpreted in order to gain the meanings behind the meaning of existing provision. The meaning of any symbol is a symbol of the relationship with other symbols. ${ }^{8}$ Society or any group such as Santana organizes their lives based on the meanings that they have from various things, particularly from their knowledge and millieu.

${ }^{3}$ Harold G. Koenig, In the Wake of Disaster: Religious Responses to Terrorism \& Catastrophe, Philadelphia and London: Templeton Foundation Press, 2006, xvi-xvii.

4j.T. Mitchel, "The Hazard of one Faith: Hazard Perceptions of South Carolina Christian Clergy", Environmental Hazard, 2, (2000), 25-41.

${ }^{5}$ Cecil Bradfield and Mary Lou Wylie, "After the Flood: The Response of Ministers to A Natural Disaster", Sociological Analysis, Volume 49, Number 4 (1989), 397-407.

6 J ohn L. Esposito, Masa Depan Islam: Antara Tantangan Kemajemukan dan Benturan dengan Barat, translated by Eva Y. Nukman and Edi Wahyu, Bandung: Mizan, 2010, 69.

'Heddy Shri Ahimsa-Putra, "Peringatan, Cobaan dan Takdir: Politik Tafsir Bencana Merapi", Masyarakat Indonesia, Volume XXVI, Number 1 (2000), 27-54.

8 James P. Spradley, The Ethnographic Interview, New York: Holt, Rinehart and Winston, 1979, 97. 
In the system of meaning, the terms using by informants are the symbols that are relate to each other. It is the road which makes it possible to decipher the meaning of the rich symbols. Cultural symbols are a cultural category; the terms of informant are the main types of cultural symbols. In addition, the symbols not only come from informant terms but also their practices that I scrutinize from the view of key symbols. An essential element in understanding the social practices are focused on real people and real things ${ }^{9}$ through the peak symbols or what Sherry B. Ortner said as key symbols. In this paper, key symbol of Santana's practices is the concept of mustad'afin or disaster victims as weak people.

In obtaining these data from informants, I lived in the hamlet of Turi where Santana stayed there to help flood disaster victims. I tried to engage in some activities of the Santana group on disaster response. Based on classical symbolism perspective, I applied ethnographic method to collect data through several steps such as interview, focus group discussion, and everyday life observation.

\section{Religious volunteer group of Santana}

Santana is an acronym from santri tanggap bencana (I slamic student's response to disaster) which is a collection of students from pesantren (Islamic boarding school) Sumber Pendidikan Mental Agama Allah (Source of Allah's Religious Mental Education) or SPMAA. This pesantren was established in 1961. Unlike the other pesantren in Java, SPMAA has not only young student but also old student. Based on age categories, there are 35 students of 7-12 years old, 177 students of 13-30 years old, 110 students of 21-55 years old, and 42 students of 56 years old.

'Sherry B Ortner, "Theory in Anthropology Since the Sixties", Comparative Studies in Society and History, Volume 26, Number 1 (1984), 144. 
Total number of student currently reach 364 students. It has old student because all of old students are poor and homeless. This is part of their mission to practice Islamic tenets in their everyday life. Related this mission, twenty students were founded Santana group when they are facing flood disaster on 2008 in their village, Turi village in Lamongan, East Java. Santana group is under pesantren SPMAA orders. But, it is independent in organising programs, submitting fund-raisings, and recruiting members.

This group consists of senior students and pesantren leader or kiai's family. The members of Santana are twenty students including kiai's wife and his four sons. Adhim, one of kiai's sons has become chairperson of Santana. He is just 27 years old. He usually manages the programmes and coordinates action plans of Santana. Together with senior santris of pesantren SPMAA, he attempts to design programmes. Because the flood and other disasters usually come suddenly, its programme and plans applied anytime when it is needed. All members are always ready if the leader gives instruction to move and act in helping victims.

As an autonomous organization, Santana has functional divisions. In each division, there are members comprised of students and professionals. Division was held based on the consideration that each member has a role and function as needed in providing disaster emergency services. Here are the divisions in the Santana and functions: 1) mediSANTANA, this division is tasked with giving medical help such as drug distribution and disease prevention through counseling; 2) evakuaSANTANA, this division is in charge of looking for or evacuating disaster victims at the scene and then taken to a place of refuge or a safer place. The services provided are the search and evacuation of disaster victims to safer places; 3) distribuSANTANA, 
this division is responsible for registering the needs of refugees, collecting and then distributing them to survivors in need; 4) informaSANTANA, this division is responsible for providing detailed information about the services being carried out by SANTANA; 5) logiSANTANA, this division is in charge of preparing SANTANA volunteer needs ranging from equipment, shelter, landing sites, to consumer needs; and 6) daiSANTANA, this division is a central division to instill spiritual strengthening of disaster victims. For the psychological condition of survivors recover from adversity and trauma, then the task of this division is to carry out activities such as reducing the burden of rapport, educating or entertaining and rescuing. Their activities are usually packed in the form of counseling, school happy, storytelling, recitation, prayer, and retreat.

\section{Santana's perspectives on the meanings of disaster}

Natural disaster is not just natural event but socio-cultural phenomenon. As socio-cultural phenomena, it is important to understand the meanings of disaster given by any society such as Turi village inhabitants, particularly Santana group. The meanings of disaster show how they were respond it because their social practices is relate to their understanding or meaning to disaster event. Here, I want to explore the influence of religious aspects as part of cultural aspects in responding disaster, particularly from the perspective of Santana who emphasizes religious aspects and attempts to realize religious values in everyday life.

I lived in SPMAA pesantren where Santana group is located. I got involved with Santana's practices and activism in Turi village before and after flood disaster. I focused on twenty Santana's members. I found different views between one santri and other santris to the disaster events. When I interviewed and communicated with them, they raised 
kinds of symbol through their languages and actions. These symbols appeared in a different language and terms as a personal reflection of each santri for reaction to disaster events through their knowledge.

All of the symbols raised by the Santana group are six symbols that closely associated with meanings given by Santana on the flood events. The five symbols are 'warning of Allah', 'Allah tests', 'punishment and azab of Allah', 'environmental damage', and 'natural events'. These five symbols include symbols that tend to use religious languages, including the terms of Qur'anic verse as azab Allah. These symbols can also be distinguished according to its reference where each symbol has a relationship with other symbols and complement each other to form their own meanings. After I identify these five symbols, there are two possible categories: theological and natural category.

The first category is "theological" category. This category includes the symbol of Allah's warning, a test of Allah, and punishment and azab of Allah. Three of these key symbols have approximately the same reference that is referring to the verses of the Qur'an as the basis of their belief. Because the reference is the Qur'an that it is divinity, I think symbols are included in the category of theology, where God of Allah becomes the basis of the main considerations when santris brought up the symbols of flood events in the environment.

One of the Santana members $(m, 26)$ said that disaster was the warning of Allah. He believed that Allah created disaster because people were not obedience to religious rules. In addition, he also assumed that the moral decadence of people such as corruption made unbalanced condition. Therefore, according to him, Allah created the flood.

Flood is only two days. But, the houses are flooded by water. Perhaps, it is cause by people itself which is not active in praying and good deed. It is warning from Allah. Allah has informed through this warning. Yeah...in order to make people godlier and piety. 
Indeed...Indonesian moral are decadence. Many cases of corruptions showed on our television. In the upper (village) level, the government officers are also do same thing. On that account, flood disaster is given by Allah for us. ${ }^{10}$

The other three santris ( $f, 23 ; m, 26 ; m, 42$ ) have the same views. They believed that disaster was warning from Allah because Indonesians were not aware of their environment. One of them said that flood occurred because people were dhalim (despotic) and were not aware of Allah's warning. "In essence, Allah wants people to live peacefully and happily without disaster. But, because they are dhalim, Allah give them warning through disaster."11

The different perspective came from other santri $(m, 26)$. In the informal discussion, he argued that disaster was test from Allah. He said on stable voice:

...clear the nation is being tested by Allah. ...is test from Allah. ... test is coming regardless of wealth status, age status, or whether someone is ready to deal with it, but the test came to every creature from the creator of universe can draw a lesson for. Disaster in Indonesia did not exist forever,... more patience and trust we face is increasingly high test our dignity before God, the love of God to increase the reward for the creature which is always patient, but if we are angry and desperate, the farther is the grace of God... just believe that God would provide a way out of every test that is given as we are experiencing now. ${ }^{12}$

On the other perspective, four santris ( $\mathrm{f}, 23 ; 24 ; 51 ; \mathrm{m}, 35$ ) tried to relate the disaster with Qur'an explanation. A female informant of Santana described disaster as form of moral consequences. She argued that it was a punishment from Allah because people were refusing to Allah orders.

\footnotetext{
10Interview, 20 August 2010.

${ }^{11}$ Interview with female member (23), 22 August 2010.

12Interview, 26 August 2010.
} 
...disaster was caused by human actions themselves. The existence of the flood disaster is a punishment for people in order to do good thing and always practice the religious rules. If they are collided with religious rules, Allah will give them punishment such as disaster in Indonesia recently. This opinion is available in our holy book of al-Qur'an al-Karim. ${ }^{13}$

In the same meaning, the other santris stated that disaster was not just punishment but azab. For them, azab is a terrible punishment that is explained directly in the Qur'an. This term is usually used in the great cases as prophet of Hud story and prophet of Nuh story.

This event is the azab as prophets story in the Qur'an. God inflicted on the prophet Noah because of their refusal and disbelief. For the prophet Noah himself, the incident is a severe test. Because with his own eyes from the ark, he witnessed his biological children disappeared under the waves. Which parent bear to see her swallow the big wave of agony, while he was safely on top of an ark. So, this is a trial that was so hard for the Prophet Noah, but disaster is a azab on his ummah. ... all the major disaster that ever happened to humans is explained by the Quran and always associated with disbelief and disavowal man himself to God. ${ }^{14}$

Punishment and azab of Allah are symbols that showed the meaning of disaster according to Santana. Both punishment and azab are based on the Qur'an explanation as a source of santri's knowledge. The tendency of such meaning is indeed owned by most religious adherences. In Egypt, for example, when an earthquake occurred on October 12, 1992, the population of Egypt is mostly Muslim connecting these natural disasters to the 'Day of Judgment'15 and the anger of

\footnotetext{
${ }^{13}$ Interview, 25 November 2010.

${ }^{14}$ Interview, 26 August 2010.

${ }^{15}$ J acqueline Homan , "A Culturally Sensitive Approach to Risk? 'Natural' Hazard Perception in Egypt and the UK", Australian J ournal of Emergency Management Volume 16, Number 2 (2001), 14-18.
} 
$\mathrm{God}^{16}$ which was directly connected with the explanation of the Quran. More or less the same case also happened in Turkey during an earthquake in 1999. In a survey in the city Mehmetcik Tented, Bakioglu and Gammage found that about 50 percent of respondents thought that God had punished them, 15 percent said the fate and 5 percent believed that the disaster was the sign of the Judgment day. ${ }^{17}$ The evidence of religious explanations of natural disaster events, which was always associated with religious teachings, clearly showed the position of God as the creator or actor of the natural disaster event.

The second category is the "natural" category. This symbol refers to the natural reality which is considered as a factor causing the flood. Because santris looked at the catastrophic events as a result of natural processes that are not balanced, I think this is included in the natural category, in which knowledge of natural processes is the conclusion of santris on disaster events.

Giving meaning as a process of natural disasters explains how Santana santri tried to interpret the disaster not only as the act of God (theology), but also as a natural event or the act of nature. One of Santana member $(m, 35)$ commented on natural disasters as the act of nature was showed that disaster was caused by natural processes. In relation to flood events that plagued the population of Lamongan last few years, from 2007 to 2010, he interpreted it as the process of uncertain climate change and these changes were influenced by human activities. He explains:

${ }^{16}$ acqueline Homan, "The Social Construction of Natural Disaster: Egypt and the UK", in Mark Pelling (ed.), Natural Disasters and Development in a Globalizing World, London: Routledge, 2002, 141-156.

${ }^{17}$ A. Bakioglu and P. Gammage, "What did we learn after the Earthquake?", National Hazards Society Newsletter, Volume 13, Number 2 (2001), 3-4. 
...if in Lamongan, we assert that natural disaster occurred because of environment damage caused by human actions... But who confirmed this is that environmental damage due to acts of our hands. That the nature of damage is influenced from human actions that destroy nature by cutting down the tree as good as his own, littering, excessive exploitation of nature. We also provide rational explanations to the inhabitants, such as the existence of local knowledge that should not be cut down trees that are considered sacred and there are apparitions. We explained that it is not the watchman that caused the tree should not be felled, but the tree is able to maintain the existing ecosystem can absorb water and then into ground water that are beneficial to human being. ${ }^{18}$

In a speech forum, one of the facilitators (member of Santana) emphasized an understanding of natural disasters as a purely natural event. This statement certainly raises the consequence that flood disaster is considered as a purely natural process and does not involve the roles of God as the opinion of Santana's previous students (on theological category). He explained natural events from an essentially different point of view from the actual other Santana students. He said:

... this is purely natural events. We are creatures created to always do good deed to human being and nature. Do good on this nature are referred to in the Qur'an as an act which is important to maintain the preservation of the environment to avoid the events of floods and other disasters. ... That this disaster is really purely natural events. Allah has entrusted nature to human beings. We are told to protect nature in order to remain sustainable. But if not preserved, not one human being overwritten gusti Allah when floods. ${ }^{19}$

From the differences of symbols that were raised by Santana members above, two categories of meaning that raised through the symbols showed the diversity of student's perspective toward natural disasters. Meanings that can be understood through the terms

18Interview, 5 August 2010. 
or symbols that appear above showed the disaster as natural phenomenon because the intervention of God. Disaster regarded as a guide for human being who is considered by Santana as no longer doing good or God's teachings.

Two categories above, "theological" and "natural" category, are the real experience of negotiation and contestation given by Santana members. Human being or disaster victim was placed in a theological view as an object that is responsible to God and human being for their actions of "wrong doing" (not in accordance with the teachings of the al-Qur'an, such as corruption) on the one hand and the victim as a subject that was responsible for their actions of natural damage and environment on the other hand. The first category attempted to place disaster victim as a patient who had received the results of their deeds given by God. It was theological tension. On the other hand, the second category as the perpetrator of environmental destruction was very natural tension. The two categories were mutually influencing and usurp the position of the symbols and meanings that was raised by Santana as disaster response volunteer as well as disaster victims. Judith Schlehe, when examining the discourse of the volcanic eruption of Merapi, concluded a plurality of meanings to natural disasters. According to her, the interpretations of the meaning of natural disasters were contested and negotiated forever. ${ }^{20}$ Negotiation and contestation of meaning that occurred actually not independent. That is, the theological category actually had a strong influence on Santana's perspective in understanding nature, and natural categories also affect their theological outlook. Both of them affect each other and in turn

20] udith Schlehe, "Cultural Politics of Natural Disasters: Discourses on Volcanic Eruptions in Indonesia", in Michel J. Casimir and Ute Stahl (ed.), Culture and the Changing Environment: Uncertainty, Cognition, and Risk Management in Cross-cultural Perspective, Oxford/New York: Berghahn, 2007. 
are manifested on social practices against victims of disaster response activities.

\section{Santana's perspective on the meanings of victimhood}

The meaning of disaster does not mean anything for Santana group without the consideration of human elements who became victims in its extreme natural events. As the previous discussion that showed the meanings given by Santana against catastrophic events, the differences in meaning that emerged was the reflection of their knowledge and experience dealing with catastrophic events. Meaning was given by Santana members were very closely related not only to material aspects of disaster but also on their view of the human beings or disaster victims.

Disaster victims are often targeted for errors or defendant in the event of disaster. One example is the view of Santana member $(m, 26)$ who put the victim as a person who is considered negligent towards religious orders so that God becomes angry. Warning of God for him is evidenced by catastrophic events. With no further ado, he argued "... perhaps this flood is caused by human beings themselves because they are less active worship and pious deeds multiply."21 This opinion puts the position of the victim as the guilty person so that he gets a warning from the God through flood disaster.

These perspectives and opinions are not only owned by Santana but also religious groups and religious communities in general. In the case of the earthquake in Alor (2004), Campbell-Nelson explained one of the response given by the Christian community there, especially church leaders, was put disaster as 'God's Judgment on the Sins of

\footnotetext{
${ }^{21}$ Interview, 20 August 2010.
} 
people of Alor.'.22 The victims once again are accused or might be "accused" because it was placed as the sinners (Sins of people of Alor). In the same case, we understood the victims of religious groups in Bangladesh" ${ }^{23}$, Egypt ${ }^{24}$, and Turkey ${ }^{25}$ as well. I use the word "accused" here because I believe that not all the affected victims were sinners as categorized by church leaders, as well as other religious groups like Santana.

Dealing with disaster victims as sinner, Santana's chairperson attempted to explain to me that the victims could be linked to the concepts of the Qur'an about the people who deserved a helping hand from someone else. By referring to the doctrine delivered by the founder of the pesantren SPMAA, kiai Muchtar, he viewed victims of the disaster as being weak and must be assisted by other Muslims.

... the process that we passed up to now this is an inspiration and a follow-up of thoughts that have been formed by Mr. Muchtar. ... he reminds us to see that the condition of society has been damaged because it has so long been left by the shepherd "Messenger of Allah", prophet Muhammad. One of inspiration for us is the verse of al-Maun. It reminds us that although we had memorized the Quran, or the other about everything but if we do not care about the fate of the poor then we are liars of religion. Indifferent to the fate of the poor, orphans, people hard, panic, or stress can be translated as mustad'afin that we are indifferent to social facts around you, ... that's just the same we reject religion. One of this type is not care with mustad'afin. ${ }^{26}$

\footnotetext{
${ }^{22}$ John Champbell-Nelson, "Religion and Disaster: Critical Reflection Post Alor Earthquake 2004', Working Papers, 8 (2008), 6.

${ }^{23} \mathrm{Hanna}$ Schmuck, "An Act of Allah: Religious Explanation for Flood in Bangladesh as Survival Strategy", International J ournal of Mass Emergencies and Disasters, Volume 18, Number 1 (2000), 85-96.

${ }^{24}$ acqueline Homan, "The Social Construction of Natural Disaster: Egypt and the UK".., 14-16.

${ }^{25} \mathrm{~A}$. Bakioglu, "''What did we learn after the Earthquake?...,3-4.

${ }^{26}$ Interview, 4 September 2010.
} 
As the views of Santana chairperson above, mustad'afin is seen as a human being trapped in a state of helplessness. Disaster victims are placed in the category of people who are powerless against the conditions and realities of life. The factors that cause disability in at least coming from the natural factors that make them are in a difficult atmosphere. Wood that is usually used to make the fireplace had been soaked by flood. Natural situation is exacerbated by social factors that create injustice for victims of disaster. Disaster assistance is not evenly distributed and controlled by some of the powerful persons in structural impoverishment. Residents who are poor did not obtain food rations that should be accepted. In contrast, most rich people just piled the food aid from outside the village of Turi. These conditions automatically created an atmosphere of helplessness and misery for flood victims.

The situation of the inhabitants was classified by Santana as dhu'afa (weak people) who gave birth to a new poverty and new orphans. Santana groups classify the victims as poor based on the view that victims are unable to meet daily needs, loss of property, it is difficult to obtain the necessities of life and did not even have a place to live (live in refugee camps). Khosyi'in, one of the Santana member said that "the victim is tantamount to the poor as described rather than the Quran. They had suffered, could not get daily needy. It had to be helped because Islam commands for helping the poor."27

On the other hand, Santana looks at disaster victims as orphans because they have similar conditions and circumstances to orphans. Orphans were defined by Santana as the children abandoned by both his father and mother. Santana looks the children who were victims of disaster just the same as those who do not have a mother or father

${ }^{27}$ Interview with Khosyi'in, 25 August 2010. 
because his parents will not have time to give full attention. So, disaster victims are signified by Santana as a class of weak people or mustad'afin which included the poor and orphans. The concept of mustad'afin (weak people) is the key symbol that reflected Santana's perspective to disaster victims.

As I have mentioned above, the reasons advanced by Santana in placing the poor and orphans as weak people or du'afa (mustad'afin, pl. Arabic) based on a verse in al-Maun verse of the Qur'an. This verse has inspired Santana when looks at disaster victims as a class of mustad'afin. Santana departed from the view of social reality that occurred in their neighborhood which was the number of disaster victims who need help. Disaster victims are then interpreted by Santana as the weak people, needed help and even target of zaka distribution, a giving concept in Islamic charity. Two important issues addressed by the verse of alMaun, according to Santana, are the issue of orphans and poverty that called as mustad'afin. This verse emphasizes that Muslim is not lawful to do rituals in prayer when they ignore poor people and orphans.

Children victims of disaster are part of the target of Muslim obligations. Child victims of disasters are juxtaposed with the orphans that must be observed by Muslims. The Qur'an made it compulsory for all Muslim and give maintain his rights as weak human beings. Some of the charity concepts in Islamic teachings, such as zaka, infaq, and sadaqa also will lead to orphans including children victims of disaster as in Santana's understanding. Thus, the results of zaka, sadaqa or infaq can be given to children victims of natural disasters as a category of the weak human beings (mustad'afin).

According to al-Mawardi in J onathan Benthal explanation, the principal ritual practices of Islam (pillars of Islam), such as prayer, zaka, fasting, and hajj are the formation of human consciousness in the fight 
against the ego to other human interests. ${ }^{28}$ Ritual practices in turn are trying to create a balance of social life in which the poor and orphans will receive help from others so they can live well and do not suffer. These practices, al-Mawardi argued, is also expected to form the Muslim mentality to be able to be responsible in their social environment.

Al-Maun verse which was mentioned by Santana in the sense of disaster victims gave an explanation of the importance of prioritizing social piety than spiritual piety. This verse emphasizes sharp criticism to Muslims who diligently perform the ritual, but exclude the poor and orphans. Muslims who diligently carry out rituals such as prayer called by a liar religion and secured with hell if they do not help the poor and orphans. Santana member said that "it reminds us that although we had memorized the Quran ...but if we do not care about the fate of the poor then we are liars of religion."29 This statement of Santana member clarified that the verse of al-Maun has been a cornerstone in place disaster victims who are considered as a group of mustad'afin, namely the poor and orphans.

\section{Social practices}

Social practices are part of the practices carried out when the Santana group is facing a catastrophic event in their environment. Following Sherrry B. Ortner's view, besides thinking, key symbols can be found on the physical practices performed by Santana. Santana's response to disaster showed how this group has made a real effort physically for victims of natural disasters.

\footnotetext{
${ }^{28}$ Egbert Harmsen, Islam, Civil Society and Social Work: Muslim Voluntary Welfare Associations in J ordan Between Patronage and Empowerment, Amsterdam: Amsterdam University Press, 2008, 178.

29Interview, 4 September 2010.
} 
Disaster response activities when Santana faced an extreme natural event that made most of the population have suffered from mental stress and economic hardship was a practice that had a connection with their views for victims of natural disasters. When they viewed the disaster as an act of God or a result of the destruction of nature, this view did not necessarily make Santana move to practice disaster response activity. A quite understandable from the link between discourse and practice of these physical is how these groups gave meaning to the disaster victims. The victim was placed as a figure of a helpless, weak people (mustad'afin) as well as sinners and Kufr. Through the Qur'an commands that kind of people should get attention and help, I believe that the social practices of disaster response were related to the understanding of disaster victims into social practice.

As a group that stood in the boarding schools or pesantren that had a leader, we could not ignore the role of Santana leader against social practices as disaster response. However, in the process of leader decision to practice of disaster response, I understood the transformation of ideas deciding that occurred between one member and other members of Santana. For example, when it will perform in Lamongan disaster response activities, coordination and communication occur between female leader, male leader and chairperson of Santana. These people are involved in a joint decision when going to practice disaster response. However, the decision was clearly not immune from a concept, perspective and discourse of disasters and disaster victims. Practices such as the provision of post disaster response displacement, evacuation, provision of logistics to the victims, disaster prayers and happy school for children victims of the disaster were the physical part of an understanding of disaster victims. 
One santri described his experiences when rescuing flood victims. By using rubber boats, four members of Santana gone around villages inundated water as high as the roof. They began searching since late afternoon after the Solo river water overflowed and flooded the village flows. The victims who had been evacuated to refugee camps, about ten o'clock at night, Santana did not manage to persuade a grandmother who is sick to be evacuated. According to Santana, the grandmother was resigned to death and will stay on the roof of his house. After going through a long debate, finally the old lady had been evacuated at $11.30 \mathrm{pm}$.

I managed to remove the victim at half past eleven the night, flooding has been two days. There is a sick old man, then let go, do not want to move from place to evacuate, then I say: I understand busy, I am a person who was ordered by God to help ibu out of this place.

When Santana performed disaster response activities, they were also organizing both maghrib prayer and isya prayer, there were additional qunut intended as a way to ask God's help in an atmosphere of panic. A division of Santana, daiSANTANA, chanted qunut in the last maghrib prayer and isyak prayer'. In qunut, he recited the prayer:

"Allahummah dini fi man hadait, wa 'afina fi man 'afait wa tawallana fi man tawallait, wa barik lana fi amn a'toit, wa qina syarro ma qodoit, innaka.... tabarokta wa ta'alait."

["O Allah, give us clues as people who have been you have guided. Save us in the class of people who you have to keep. ....among the people whom you care ... Avoid us from all dangers that you have set ..."]

Qunut chanting above was intended to God to bring relief to disaster victims. This meant was the gift of salvation God's help for disaster victims and their belongings, nor the magnanimity to accept the reality 
of disaster with patience and submission to God. These were the main objectives qunut performed by Santana, along with the survivors.

This research mentioned in my Disaster Responses acts as a social practice because Santana groups have different meanings for natural disasters, physical, perform disaster response actions through practical activities such as building refugees place, evacuation, medical services, and provision of logistics, prayer disaster, and happy school. Through these activities I noticed that each purport Santana santri had its own disaster meaning which can be fused together in an act of disaster response. In the social spectacle, the practices can be referred to as the efforts of social activism because it is a practice that had an influence on social life in this study is the recovery of disaster victims.

All forms of Santana response came as a result of thinking that God will give guidance to victims. Through prayer and supplication for forgiveness, the victims had, according to Santana, at least expectation to continue their everyday life. Religious approach, such as Santana action, had also been put forward by Hanna Schmuck when observing local poor community adaptation strategy in case of floods in Bangladesh in 1991 in which the outsider considered the approach did not help. ${ }^{30}$ However, Schmuck found the sides of the reinforcement in the way of local community. Schmuck concludes that:

For the outsider, the rural people in Bangladesh seem to be helpless victims of hazards, accepting them as an act of Allah. ....in the view of aid agencies, this perception and explanation hamper both external as well as indigenous efforts to survive disasters. ...this conception is a healthy reaction, and therefore is a self-help strategy to overcome crises as quickly as possible and return to daily life. As Allah has given the floods, He will also give believers the strength to survive them. ${ }^{31}$

\footnotetext{
${ }^{30}$ Hanna Schmuck, "An Act of Allah..., 86.

${ }^{31}$ Hanna Schmuck, "An Act of Allah..., 92.
} 
Dealing with religious communities' response to natural disaster, Jacqueline Homan also agreed the response of the religious belief that fatalistic in the face of disaster. He argued that "... it would be wrong to assume that this result in a fatalistic attitude towards disaster. Religious explanation is meaningful to people but very few felt that this precluded practical action." 32 From this statement it appeared that the explanation of religion did not prevent religious people or religious community such as Santana perform practical action towards disaster.

Actually, religion provides the opportunity and the values for the adherents to understand the phenomena that occur in their environment and respond to these symptoms for the benefit of man and his environment. Based on religious communities' response, religious tenets give values when his own followers, whether it be individual, group or organization able to provide interpretation to suit the local context where believers are to live and settle. Recognized or not, religious groups as Santana and community organizations has indeed been instrumental in assisting the recovery of victims of natural disasters. In the case of hurricane Katharina, FEMA, government and other religious groups provided rapid responsible assistance to the victims. ${ }^{33}$ In the case of the tsunami disaster in Aceh and the eruption of Merapi in Yogyakarta, dozens of groups and religious organizations provide relief to victims of disaster as well.

\section{Concludingremarks}

As a group of Islamic religion who has the foundations of the way of life, Santana group showed religious meaning when responding to natural disasters on their environment. Religious meanings that emerged as

32 J acqueline Homan, "The Social Construction of Natural Disaster: Egypt and the UK".., 147.

${ }^{33}$ Harold, In the Wake of Disaster..., xvii. 
a commentary on the occurrence of natural disasters were understood by Santana from an understanding of scriptural text, particularly the Qur'an. Because the natural disaster event was understood from the viewpoint of explanation of the Qur'an, then the dominant symbols that appear on their perspectives were religious symbols.

Although the meanings were raised by Santana on the disaster was greatly religious, it does not mean ignoring scientific knowledge and social considerations. Through the key symbols in social practice on disaster response, Santana showed how the disaster and its victims were seen as weak human (mustad'afin) who should receive the attention of mankind. Mustad'afin category was central symbol raised by Santana as their interpretation of religious texts and explanations of social conditions of disaster victims. Meanings that were performed by Santana on disaster and disaster victims, in turn, was not be fatalistic, leaving the victim as a sinner, but rather provided an alternative to disaster risk reduction through spiritual guidance embodied in the practice of prayer while also providing physical assistance such as evacuation of causalities.

\section{Bibliography}

Ahimsa-Putra, Heddy Shri, "Peringatan, Cobaan dan Takdir: Politik Tafsir Bencana Merapi", Masyarakat Indonesia, Volume XXVI, Number 1 (2000): 27-54.

Benthall, J onathan, "Have Islamic Aid Agencies a Privileged Relationship in Majority Muslim Areas? The Case of Post-Tsunami Reconstruction in Aceh", J ournal of Humanitarian Assistance,( J une 26, 2008) accessed from http://sites.tufts.edu/iha/archives/153 at 25 Desember 2010. 
Bradfield et al., "After the Flood: the Response of Ministers to a Natural Disaster", Sociological Analysis, Volume 49, Number 4 (1989): 397-407.

Chester, David K., “Theology and Disaster Studies: The Need for Dialogue" J ournal of Volcanology and Geothermal Research, Number 146 (2005).

Chester, David K. Volcanoes and Society. London: Edward Arnold, 1993. Esposito, J ohn L. Masa Depan Islam: Antara Tantangan Kemajemukan dan Benturan dengan Barat. Eva Y. Nukman and Edi Wahyu (trans.). Bandung: Mizan, 2010.

Homan, J acqueline, "The Social Construction of Natural Disaster: Egypt and the UK" in Mark Pelling (ed.). Natural Disasters and Development in a Globalizing World. London: Routledge, 2002.

Homan, Jacqueline, "A Culturally Sensitive Approach to Risk? 'Natural' hazard perception in Egypt and the UK", Australian Journal of Emergency Management, Volume 16, Number 2 (2001).

Koenig, Harold G. In the Wake of Disaster: Religious Responses to Terrorism \& Catastrophe. Philadelphia and London: Templeton Foundation Press, 2006.

Manzoor, Pervez, "Lingkungan dan Nilai-nilai dalam Perspektif Islam”, Ulumul Qur'an: J urnal Islam dan Kebudayaan, Volume II, Number 9 (2004).

Mitchel, JT., "The Hazard of one Faith: Hazard perceptions of South Carolina Christian Clergy", Environmental Hazard 2 (2000): 25-41. Oliver-Smith, Anthony, "Anthropological Research on Hazards and Disasters" Annual Review of Anthropology, 25 (1996): 303-328. 
Ortner, Sherry B., "Theory in Anthropology Since the Sixties, Comparative Studies in Society and History, Volume 26, Number 1 (January 1984): 126-166.

Ortner, Sherry B., "On Key Symbols" American Anthropologist, New Series, Volume 75, Number 5 (October 1973): 1338-1346.

Quarantelli, E.L. and R. R. Dynes, "Response to Social Crisis and Disaster", Annual Review of Sociology, Volume 23, Number 3 (1977).

Schlehe, J udith, "Cultural Politics of Natural Disasters: Discourses on Volcanic Eruptions in Indonesia," in Michel J . Casimir and Ute Stahl (ed). Culture and the Changing Environment: Uncertainty, Cognition, and Risk Management in Cross-cultural Perspective. Oxford/ New York: Berghahn, 2007.

Schmuck, Hanna, "An Act of Allah: Religious Explanation for Flood in Bangladesh as Survival Strategy", International Journal of Mass Emergencies and Disasters, Volume 18, Number 1 (2000): 8596.

Shook, Gary, "An Assessment of Disaster Risk and its Management in Thailand", Disaster, Volume 21, Number 1 (1997): 77-88.

Spradley, J ames P. The Ethnographic I nterview. New York: Holt, Rinehart and Winston, 1979.

Stern, Gary. Can God Intervence?: How Religion Explains Natural Disaster. London: Preager, 2007. 